\title{
Costs and benefits of developing nature areas: regional versus national impact
}

\author{
E. J. Bos ${ }^{1} \&$ J. M. Vleugel ${ }^{2}$ \\ ${ }^{1}$ LEI B.V., The Netherlands \\ ${ }^{2}$ OTB Research Institute, TU Delft, The Netherlands
}

\begin{abstract}
Developing nature areas generates various benefits for the economy. The main benefits concern growing incomes for the recreation sector (hotels, camping, restaurants, etc.), higher prices of houses, etc. In this study the costs and benefits of developing nature in a rural area in the south-east of the Netherlands have been analyzed. Our study revealed that effects for the regional economy are considerable. On the national level, however, these effects appear to be negligible. This is due to the fact that on an interregional level the effects largely balance each other out. Thus, nature development in a certain region will increase the number of visitors to that region, but at the expense of other regions. In other words, due to substitution effects the net interregional effect of nature development on recreational spending is negligible. This raises the question whether the national government should finance regional nature development. Keywords: economic valuation, regional impact, national impact.
\end{abstract}

\section{Introduction}

Cost-benefit analysis (CBA) has become an important tool for supporting policy decision making on public investments project such as infrastructure and land use scenarios. In this article, the impact of a nature development scenario in the Netherlands will be elaborated, first from a regional perspective and next from a national perspective.

The question that will be elaborated on in this paper is whether the scale at which the evaluation of such a regional investment plan takes place has an impact on the outcome of the CBA. 
The set-up of the paper is as follows. Section 2 shortly introduces cost-benefit analysis, and in particular indirect effects. Section 3 is devoted to the case study, in which costs and benefits are calculated on a regional scale as well as on a national scale. In section 4 conclusions and recommendations can be found.

\section{Cost-benefit analysis and indirect costs}

In the literature on CBA there is a continuing discussion concerning economic valuations of effects of (public) investments. Some [1] argue that while indirect effects are important, their share in the total impact of such investments is only small. This latter statement is too strong. In our opinion these impacts may vary depending on the case. In an earlier article [2] we have already shown that external effects can be considerable.

In the case study, which will be described below, we will discuss the most important indirect impacts of a plan to develop a nature area. These include:

- $\quad$ the dynamic multiplier to assess the impact of (for instance) recreational activities through time;

- a correction for so-called partial crowding out: development of a recreation area at location $A$ reduces income from recreation at site $B$ (or the economy as a whole);

- (prevention of) excess burden for the government budget: with a fixed budget, investments in project $A$ should be compensated by budget cuts elsewhere in the economy or the other activities in the economy should create a higher revenue than necessary in order to compensate the government budget.

\section{The case study}

\subsection{Introduction}

The Dutch Ministry of Agriculture, Nature and Fishery has made a policy document, which contains the strategic considerations of its nature policy. Its main aim is the following ([3], p. 11): "To maintain, repair, develop and sustainably use nature and the landscape, as an essential contribution to a liveable and sustainable society". In this context, sustainable development implies that the needs of current generations concerning nature are met, without reducing the possibilities of future generations (derived from [4]). In order to meet the concerned objective various nature development scenarios have been implemented in the Netherlands. One of them being the case we consider in this article: the Roerdal case.

A plan was made for the Roerdal area located in the so-called WCL-area (WCL stands for Valuable Cultural Landscape) 'Middle Limburg' in the province of Limburg, the Netherlands. WCL-policy has led to a qualitative increase of nature in the Roerdal area. This has attracted more visitors (tourists and people living in the neighbourhood). 


\subsection{Case A: CBA without indirect impacts}

A CBA for this area was made without incorporating indirect effects $[5,6]$. It had the following elements (see also Table 1):

1) Costs of landscaping and infrastructure

These costs are 350.000 Euros per year for the period 1994-2000, mainly paid by the national government and municipalities.

2) Net value added of firms dependent on recreation

Between 1994-2000 about 2 million additional visitors came to the Roerdal area. A questionnaire was used to determine on what and where they spent their money. From this dataset, net revenue (after tax) was calculated as 1.5 million Euros per year. About 1.2 million Euros was spent in restaurants and cafes, and 0.1 million on other recreational activities. Retail firms saw an increase in net revenue of 0.1 million, and other firms witnessed the same. Revenue data was then translated into net value added.

Table 1: Discounted costs and benefits excluding indirect impacts in millions of $€$.

\begin{tabular}{|c|c|c|c|c|}
\hline \multicolumn{5}{|c|}{ Impacts } \\
\hline & \multicolumn{2}{|c|}{ Costs } & \multicolumn{2}{|c|}{ Additional benefits } \\
\hline \multirow{5}{*}{ 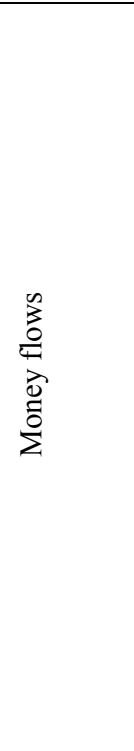 } & \multirow[t]{3}{*}{ Development } & \multirow[t]{3}{*}{2.4} & $\begin{array}{l}\text { Net added value in } \\
\text { recreation }\end{array}$ & 75.0 \\
\hline & & & $\begin{array}{l}\text { Additional VAT } \\
\text { income for } \\
\text { national } \\
\text { government }\end{array}$ & 44.0 \\
\hline & & & $\begin{array}{l}\text { Additional income } \\
\text { from } \\
\text { tourism for local } \\
\text { governments }\end{array}$ & 2.5 \\
\hline & \multirow{2}{*}{$\begin{array}{l}\text { Costs for } \\
\text { national } \\
\text { government of } \\
\text { paying an } \\
\text { additional tax } \\
\text { rebate related to } \\
\text { interest on } \\
\text { mortgages, due } \\
\text { to increased } \\
\text { housing prices }\end{array}$} & \multirow[t]{2}{*}{19.7} & $\begin{array}{l}\text { Additional } \\
\text { house owner tax } \\
\text { income for local } \\
\text { governments }\end{array}$ & 1.0 \\
\hline & & & $\begin{array}{l}\text { Additional } \\
\text { consumption by } \\
\text { house owners } \\
\text { due to higher } \\
\text { housing prices }\end{array}$ & 1.4 \\
\hline Total & \multicolumn{2}{|r|}{22.1} & \multicolumn{2}{|r|}{123.9} \\
\hline Balance & & & & +101.8 \\
\hline
\end{tabular}

Source: derived from [5] and [6]. 
3) The impact of nature on housing prices

Houses near nature (or 'green') areas have a higher price than other houses. If such houses are sold, their owner can cash this benefit or if it not sold, the house owner can arrange a higher mortgage and spend part of this benefit. The impact of more nature in the Roerdal area on housing prices is estimated as being $2.3 \%$. Following the Jade Model [7], 5\% of the rise in housing price/value is consumed [5]. For all houses this amounts to 1.4 million Euros.

4) Tax income

The national government receives 2.8 million Euros per year as additional value added tax (VAT) from the recreation sector. Municipalities receive an additional 160.000 Euros per year from tourist taxes and 0.1 million Euros per year in property taxes. Additional consumer spending due to increased housing prices also creates additional VAT-income. On the other hand, the national government gives house owners a tax rebate related to interest on mortgages.

Table 1 contains an overview of the discounted costs and benefits, based on a discount rate of $4 \%$ and a time horizon of 30 years.

\subsection{Case B: CBA with indirect impacts}

In this case the indirect impact of the project on the rest of the Dutch economy is included in the analysis in a quantitative way.

This project leads to crowding out. In other words, more recreation in the Roerdal area means less recreation in other parts of the Netherlands. We assume that this project does not have an impact on regions in neighbouring countries, like Germany or Belgium. In practice, it is likely that this impact will occur, but it will not be dealt with in order to simplify the analysis.

Full crowding out will only occur in case of absence of market disequilibria (imperfections), which is not the case. Partial crowding out is therefore an acceptable assumption.

Next to crowding out, the dynamic multiplier due to additional consumption can be calculated:

$$
\text { investments -> consumption -> income -> investments etc. }
$$

In the long-term the multiplier will go down, because the impact of the initial investment has leaked away: see Figure 1.

An excess burden of 0.3 Euro per unit of tax money is assumed.

There is an impact on recreation, housing prices and government income. This can be shown as follows.

1) Impact on net value added

The earlier value for net value added was recalculated in the following way. First, we applied the so-called rule of Harberger to correct for partial crowding out. Second, we multiplied this result by the dynamic multiplier to get the impact on the whole Dutch economy. This gave a new present value of 5.9 million Euros. 


\section{Multiplier}

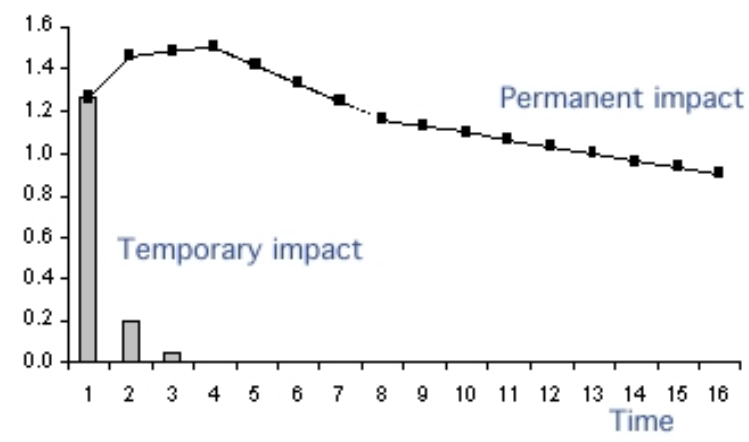

Figure 1: The dynamic impact of a permanent and one time only spending impulse of 1 Euro. (Source: [5].)

Table 2: $\quad$ Discounted costs and benefits including indirect impacts in millions of $€$.

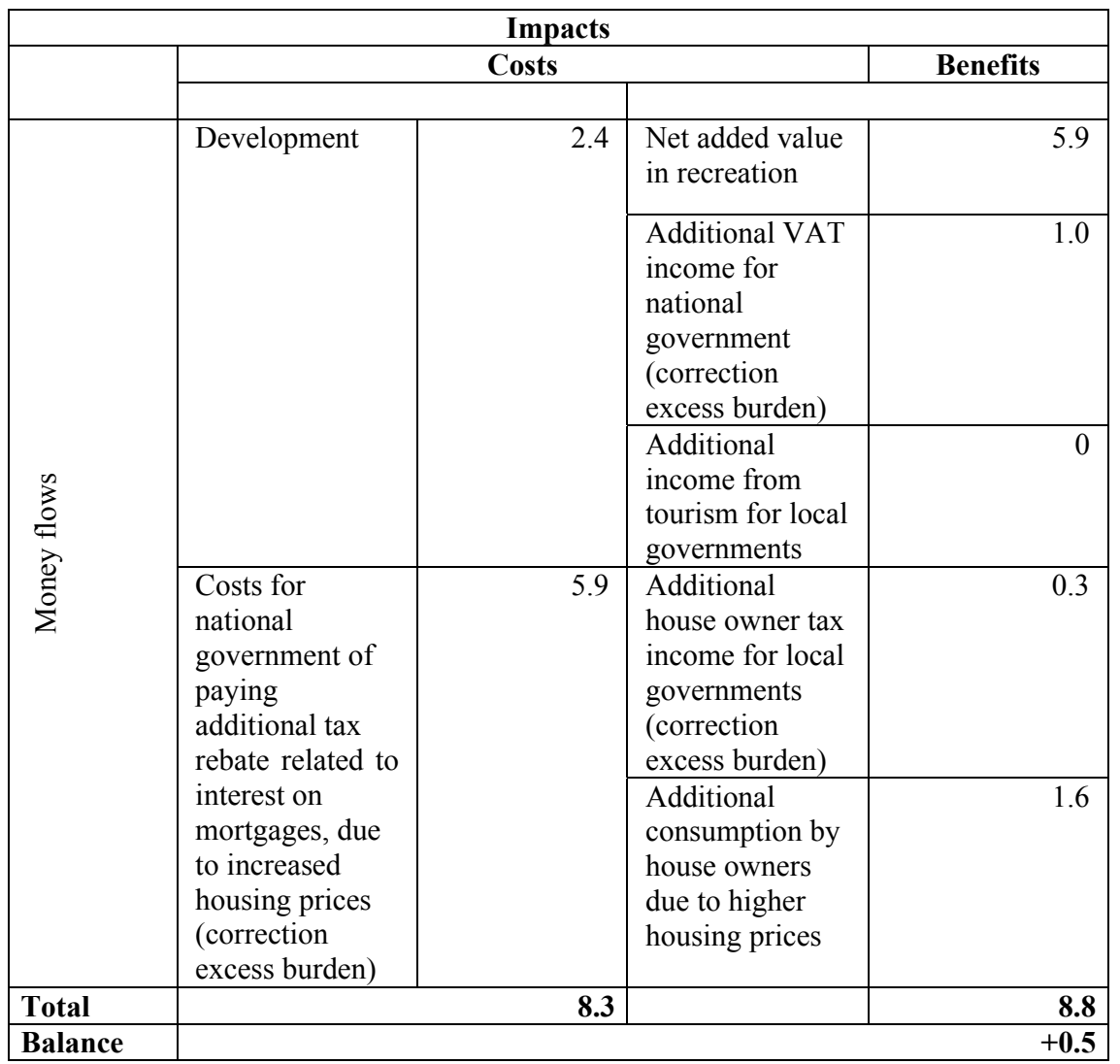

Source: derived from [5] and [6]. 
2) Impact on housing prices

The earlier figure of 1.8 million Euros was multiplied with the dynamic multiplier to get a discount value of 2.0 million Euros for additional consumer spending.

3) Impact on income and spending of governments

The before mentioned excess burden is applied to government income and spending. Tourist tax and VAT have been corrected using Harbergers' rule. In case of local government income, the aggregate of all Dutch governments is calculated instead of only the municipalities in the Roerdal area.

Table 2 contains an overview of the discounted costs and benefits, based on a discount rate of $4 \%$ and a time horizon of 30 years. This time correcting for indirect effects.

It becomes clear from table 2 that the picture completely has changed. Instead of a net benefit of 101.8 million Euros, the project has only a net benefit of 0.5 million Euros.

\section{Conclusions and recommendations}

The case study indicates that a regional investment project may have a considerable regional-economic impact, both in financial as well as in socioeconomic terms.

The national impact may be completely different, however, because the economic impulse in region has to be compensated by other areas and the national government.

By correcting CBA for indirect impacts the scale of analysis is broadened. This has a major impact on the outcome of a CBA. If regional impacts between regions cancel each other out, the question arises about the benefit of such a project for a nation; if one project 'cannibalises' another region, one could ask the question whether the national government should support the creation of new regional nature areas.

This example of what may be called competition between investment opportunities is probably inevitable if the aim of the government is to increase the total amount of nature in the country. With conventional investment projects, like those in houses, offices and infrastructure, people also accept this kind of competition and act accordingly, e.g., by changing the place where they live or work.

With respect to recreation the following reasoning is possible. More local supply means that people do not have to travel over very long distances to arrive at a green area.

\section{References}

[1] Hakvoort, J.R. and A.L. 't Hoen, Aanvulling op Leidraad OEI, in: ESB, 401- 2005, 18-20, 2005. 
[2] Vleugel, J.M. and E.J. Bos, Rondje Randstad is slecht voor de natuur, in: ESB, 20 augustus 2004, 392-394, 2004.

[3] Ministry of LNV, Natuur voor mensen, mensen voor natuur, Den Haag, 2000.

[4] Ruijgrok, E.C.M., 'Valuation of Nature in Coastal Zones'. Ph. D. Thesis. Free University, Amsterdam, 1999.

[5] Jongeneel, R., L. Slangen, E.J. Bos, M. Koning, T. Ponsioen and J. Vader, De doorwerkingseffecten van natuurprojecten op de economie: financiële en economische analyse van kosten en baten. Wageningen UR/LEI 2005.

[6] Wijnen, W., H. Hofsink, E.J. Bos; C. van der Hamsvoort and L. de Savornin Lohman, Baten en kosten van natuur; een regionale analyse van het Roerdal, rapport 4.02.09, LEI, Den Haag, 2002.

[7] CPB, JADE; A model for the Joint Analysis of Dynamics and Equilibrium, CPB Document no. 30, Den Haag, CPB, 2003. 